\title{
Effect of adding soy lecithin, xylanase and their combination to low energy diet on carcass traits, meat quality, and some blood parameters of broiler chicks.
}

\author{
Zangabel S.M. El-sayed1, Amira M. Refaie2, G.A. El-sayaad1 and M.M. Abdella1 \\ 1-Animal Production Department, Faculty of Agriculture, Banha University, Egypt \\ 2-Animal Production Research Institute - Agriculture Research Center - Dokki - Giza - Egypt \\ Corresponding author: Zangabel_saad@yahoo.com
}

\begin{abstract}
This study investigated the synergism relationship between lecithin (L) and xylanase (Xyl.) enzyme when applied to low dietary metabolizable energy (ME) on broilers carcass, meat quality and some blood parameters. 160 chicks randomly were allocated to 5 treatments, each of 32 birds ( 4 replicates of 8 birds each). The $1^{\text {st }}$ group; chicks were fed basal diet without studied supplementation (control). In $2^{\text {nd }}$ group, chicks were fed low ME diet $\left(-150 \mathrm{Kcal} / \mathrm{kg}\right.$ lower than NRC,1994 recommendation) and labeled as NC. In $3^{\text {rd }}, 4^{\text {th }}$ and $5^{\text {th }}$ groups, chicks were fed $\mathrm{NC}$ supplied with $0.5 \mathrm{~g}$ lecithin $(\mathrm{NC}+0.5 \mathrm{~g} \mathrm{~L}), 0.2 \mathrm{~g}$ xylanase $(\mathrm{NC}+0.2 \mathrm{~g}$ Xyl) and $0.5 \mathrm{~g}$ lecithin $+0.2 \mathrm{~g}$ xylanase $(\mathrm{NC}+0.5 \mathrm{~g} \mathrm{~L}+0.2 \mathrm{~g} \mathrm{Xyl})$, respectively. The growth trail lasted 35 days. The obtained results show that group of $\mathrm{NC}+0.2 \mathrm{~g}$ Xyl recorded significant increase in carcass $\%$. The lowest meat total saturated fatty acids, total cholesterol, LDL and triglyceride were achieved for group of $\mathrm{NC}+0.5 \mathrm{~g}$ lecithin. Moreover, both $\mathrm{NC}+0.5 \mathrm{~g} \mathrm{~L}$ and $\mathrm{NC}+0.5 \mathrm{~g} \mathrm{~L}+0.2 \mathrm{~g}$ Xyl recorded a significant decrease in plasma total cholesterol, triglycerides and LDL also, increase in plasma HDL compared to control.

In conclusion, addition of $0.5 \mathrm{~g}$ lecithin alone or in a combination with $0.2 \mathrm{~g}$ xylanase to broilers fed lowenergy diet is more effective in carcass, meat quality and blood plasma lipid profile.
\end{abstract}

Keywords: Broilers, meat quality, soy lecithin, xylanase, carcass traits.

\section{Introduction}

Oils are widely supplemented in poultry feed to meet the high energy demand of fast growing broilers (Patterson et al., 2012). An increase in the fat content of the diet had increase the energy value of food, but may also alter the blood lipid profile, depending on the type of fat used in broiler diets (Dubey, 2009). Hence increase broilers meat total lipids (Saleh et al., 2019).

Soybean lecithin (SL) is a by-product from the soybean oil (SO) refinement process represent an economic alternative and permit giving an added value to residual products (van Nieuwenhuyzen and Tomás, 2008), which is extracted from the SO degumming process, is mainly composed of polar lipids (> 60\%), especially of phospholipids (PL), but also contains an important amount of neutral lipids (30\%-40\%), as triacylglycerols (TAG) and free fatty acids (FFA) (Bueschelberger et al., 2015). Furthermore, SL represents a good source of phosphorus, choline and energy for broiler chickens (Mateos et al., 2012; Borsatti et al., 2018) and its combination with other fats and oils could be interesting in order to exploit positive synergies on lipid utilization (Ravindran et al., 2016). In this respect, Siyal et al. (2017) showed that broilers fed diets supplemented with $0.1 \%$ soy lecithin had significant decrease in serum cholesterol, triglyceride and low density lipoprotein concentrations (LDL) compared to control and $0.05 \%$ soy lecithin. Also, Mu and Kitts (2018) found that broilers fed diets contained 50 and $100 \%$ soy lecithin achieved significantly $(\mathrm{P}<0.05)$ higher polyunsaturated fatty acids (PUFAs) especially linoleic and $\alpha$-linolenic acids in breast and leg muscles, respectively compared to broiler fed 0 and $25 \%$ soy lecithin.

Exogenous carbohydrases such xylanase has been reported to improve energy utilization and the performance of broilers (Olukosi and Adeola 2008 ;Cowieson et al., 2010 and Williams et al., 2014) by hydrolysis of cell wall arabinoxylans and improve the access of endogenous digestive enzymes to cell contents (Kocher et al., 2003; Meng et al., 2005 and Omar et al., 2008).

Selim et al. (2019) found that adding a combination of xylanase and protease to broilers diet had a significant $(\mathrm{P} \leq 0.05)$ increase in dressing \% and a reduction in edible parts and abdominal fat compared to control group. Moreover, Saleh et al. (2019) indicated that broilers fed low-energy diet supplied with mix of Xylanase and Arabinofuranosidase enzymes had significantly ( $\mathrm{p}<$ 0.05 ) increased muscle total lipids content compared to other groups fed control or low-energy diets without enzyme supplementation. Therefore, the principal objective of the current research was to investigate the effects of lecithin, xylanase enzyme and their combination on carcass characteristics, meat quality and blood parameters in broilers fed low energy diet.

\section{Materials and Methods}

This study was conducted at the Poultry Research Farm of Animal Production Department, Faculty of Agriculture at Moshtohor, Benha University. 
Additives used in this study:-

1- Crude soy lecithin.

It is a commercial source of soy lecithin $100 \%$ which contains:-

Acetone insoluble Matter 62\%, Acid value 30\%, Peroxide value $3 \%$ and hexane insoluble Matter $0.3 \%$. The recommended level for poultry is $500 \mathrm{~g} /$ ton of finished feed.

2- Xylanase enzyme.

The activity until of xylanase is $20000 \mathrm{u} / \mathrm{g}$. This enzyme produced by Trichoderma reesei and Asperigullus niger, it's media is mineral oil $0.5 \mathrm{~g}$, rice hulls $44.5 \mathrm{~g}$ and calcium carbonate $35 \mathrm{~g}$. The recommended level for poultry is $200 \mathrm{~g} /$ ton of finished feed.

\section{Experimental diets and birds:-}

One hundred and sixty 1-d old unsexed Cobb 500 broiler chicks were weighed and randomly distributed to five treatments of 4 replicates each $(\mathrm{n}=8)$.

The five groups were follows:-
The first (control) group, received the strain recommended metabolizable energy (3000, 3000 and $3100 \mathrm{Kcal}$ during the starter, grower and finisher periods, respectively), while the $2^{\text {nd }}$ group was fed low metabolizable energy diet (NC) less $150 \mathrm{Kcal}$ than the previous recommendation levels, being 2850,2850 and $2950 \mathrm{Kcal} / \mathrm{kg}$ diet during the same growth periods. Moreover, the third, fourth and fifth groups fed NC supplemented with $0.5 \mathrm{~g}$ lecithin $/ \mathrm{kg}$ diet, $0.2 \mathrm{~g}$ xylanase $/ \mathrm{kg}$ diet and $0.5 \mathrm{~g}$ lecithin $+0.2 \mathrm{~g}$ xylanase / $\mathrm{kg}$ diet, respectively. The experimental periods lasted 35 days of age. All diets were formulated according to NRC (1994) as listed in Table (1) during starter (1-10 days), grower (11-22 days) and finisher (23-35 days) periods of growth. Chicks were housed in floor pens and kept under the same managerial, hygienic and environmental conditions. Also, chicks were provided with free access to water, feed and received the same lighting and veterinary care program during the experimental period.

Table 1.Composition and calculated analysis of the basal and tested diets.

\begin{tabular}{|c|c|c|c|c|c|c|}
\hline & \multicolumn{3}{|c|}{ Control diets } & \multicolumn{3}{|c|}{-150kcal } \\
\hline & Starter & Grower & Finisher & Starter & Grower & Finisher \\
\hline & $1-10 \mathrm{~d}$ & $11-22 d$ & $23-35 d$ & $1-10 \mathrm{~d}$ & $11-22 d$ & $23-35 d$ \\
\hline Yellow corn & 53.60 & 56.80 & 62.75 & 54.60 & 58.75 & 64.00 \\
\hline Soybean meal (44\%) & 32.75 & 33.20 & 25.55 & 36.40 & 35.40 & 28.85 \\
\hline Corn gluten $(60 \%)$ & 7.00 & 3.00 & 4.55 & 4.35 & 1.20 & 2.00 \\
\hline DI-Calcium phosphate & 1.90 & 1.90 & 1.90 & 1.90 & 1.90 & 1.90 \\
\hline Limestone & 1.30 & 1.30 & 1.30 & 1.30 & 1.30 & 1.30 \\
\hline Soya oil crude & 2.50 & 2.85 & 3.00 & 0.50 & 0.50 & 1.00 \\
\hline $\mathrm{NaCl}$ & 0.30 & 0.30 & 0.30 & 0.30 & 0.30 & 0.30 \\
\hline Vitamins and minerals mix ${ }^{*}$ & 0.30 & 0.30 & 0.30 & 0.30 & 0.30 & 0.30 \\
\hline DL-Methionine & 0.15 & 0.15 & 0.15 & 0.15 & 0.15 & 0.15 \\
\hline L-lysine HCL & 0.10 & 0.10 & 0.10 & 0.10 & 0.10 & 0.10 \\
\hline Sodium bicarbonate & 0.10 & 0.10 & 0.10 & 0.10 & 0.10 & 0.10 \\
\hline Total & 100 & 100 & 100 & 100 & 100 & 100 \\
\hline \multicolumn{7}{|l|}{ Calculated analysis ${ }^{* *}$} \\
\hline Crude protein $\%$ & 23.1 & 21.0 & 19.1 & 23.1 & 21.0 & 19.0 \\
\hline Metabolizable energy (Kcal / kg) & 3003 & 3002 & 3100 & 2853 & 2853 & 2954 \\
\hline Crude Fiber \% & 3.76 & 3.79 & 3.40 & 4.00 & 3.96 & 3.62 \\
\hline Crude Fat \% & 5.18 & 5.57 & 5.87 & 3.22 & 3.29 & 3.91 \\
\hline Calcium \% & 1.01 & 1.01 & 0.99 & 1.02 & 1.02 & 1.00 \\
\hline Available phosphorus $\%$ & 0.51 & 0.51 & 0.49 & 0.52 & 0.51 & 0.50 \\
\hline Lysine $\%$ & 1.24 & 1.23 & 1.03 & 1.33 & 1.28 & 1.10 \\
\hline Methionine \% & 0.59 & 0.53 & 0.52 & 0.57 & 0.51 & 0.50 \\
\hline Meth. + Cyc. \% & 0.97 & 0.87 & 0.84 & 0.95 & 0.86 & 0.81 \\
\hline Sodium \% & 0.16 & 0.16 & 0.16 & 0.16 & 0.16 & 0.16 \\
\hline \multicolumn{7}{|c|}{$\begin{array}{l}\text { * Each 3kg of vitamins and minerals contains: Vitamin A 12,000,000 IU, Vitamin D3 5,000,000 IU, Vitamin E 80,000 } \\
\text { mg, Vitamin K3 } 3000 \mathrm{mg} \text {, Vitamin B1 } 3000 \mathrm{mg} \text {, Vitamin B2 } 9000 \mathrm{mg} \text {, Vitamin B6 } 4000 \mathrm{mg} \text {, Vitamin B12 } 20 \mathrm{mg} \text {, } \\
\text { Niacin } 60,000 \mathrm{mg} \text {, Biotin } 150 \mathrm{mg} \text {, Folic acid } 2000 \mathrm{mg} \text {, Pantothenic acid 15,000 mg, Choline 500,000 mg, Manganese } \\
100,000 \mathrm{mg} \text {, Zinc } 100,000 \mathrm{mg} \text {, Iron 40,000 mg, Copper 15,000 mg, Iodine } 1000 \mathrm{mg} \text {, Selenium } 350 \mathrm{mg} \text {, and Cobalt } 100 \\
\text { mg. } \\
\text { ** According to NRC (1994) }\end{array}$} \\
\hline
\end{tabular}

Slaughtering and carcass characteristics:-

At 35 days of age, 1 bird per pen (4/treatment) was chosen for carrying out the slaughtering test. A total number of 20 birds slaughtered after $12 \mathrm{~h}$ of feed withdrawal. After bleeding, and feather pecking, carcass, giblets including (liver, gizzard and heart), 
spleen and abdominal fat pad were removed and weighed and proportioned to live body weight as a percent.

\section{Meat quality measurements:-}

A total number of 20 samples of breast and thigh (from birds used previously in slaughtering test) were used monitor the effect on some physical and chemical traits of broiler meat. After chilling samples at $4^{\circ} \mathrm{C}$ for $24 \mathrm{~h}$, samples were lightly blotted using filter paper before reweighing. Drip loss percent was calculated as the percentage of the difference between weights before and after chilling for $24 \mathrm{~h}$ and divided by the initial weight as described by Saenmahayak et al. (2012). Ultimate $\mathrm{pH}$ ( $\mathrm{pHu}$ ) was measured using $\mathrm{pH}$ meter, provided by a temperature control system, by probe method. The minimum depth to adopt was $1 \mathrm{~cm}$ after incision of the muscles as described by Selim et al (2013). Samples of thigh mixed with breast of the same bird were then stored at $-20^{\circ} \mathrm{C}$ for 4 days before chemical measurements for total cholesterol (TC; mg/dl), Triglycerides (TG; $\mathrm{mg} / \mathrm{dl}$ ), Low density lipoprotein (LDL; $\mathrm{mg} / \mathrm{dl}$ ) and high-density lipoprotein (HDL; mg/dl) according to Nasoetion et al. (2019). Fraction of fatty acids were determined in meat by Gas Chromatography technique (GC) according to Aura et al. (1995).

\section{Blood constituents:-}

Blood samples were individually taken using heparinized syringes at the same time of slaughtering from 4 birds of each group. Blood samples were centrifuged immediately after collection at $2500 \mathrm{rpm}$ for $20 \mathrm{~min}$. and plasma were transferred into clean tubes then stored in a deep Freezer at approximately $-20^{\circ} \mathrm{C}$ till the time of chemical analysis for Triglycerides $(\mathrm{mg} / \mathrm{dl}$ ) according to (Soloni, 1971), Total cholesterol (mg / dl), Low density lipoprotein (LDL; mg / dl) and High density lipoprotein (HDL; mg / dl) according to Richmond (1973) and Plasma liver enzymes (AST; $u / l$ and ALT; $\mathrm{u} / \mathrm{l})$ were determine according to the method of Reitman and Frankel (1957).

\section{Statistical Analysis:-}

Table 2: Effect of different treatments on carcass traits.

\begin{tabular}{|c|c|c|c|c|c|c|c|}
\hline \multirow[b]{2}{*}{ Treatments } & \multicolumn{7}{|c|}{ Carcass traits \% } \\
\hline & $\begin{array}{c}\text { Carcass } \\
\%\end{array}$ & $\begin{array}{c}\text { Liver } \\
\%\end{array}$ & Gizzard\% & $\begin{array}{c}\text { Heart } \\
\%\end{array}$ & Giblets $\%$ & Spleen\% & $\begin{array}{l}\text { Abdominal } \\
\text { fat } \%\end{array}$ \\
\hline Control & $74.79^{c}$ & 2.11 & 1.40 & 0.53 & 4.04 & 0.04 & 0.42 \\
\hline Negative control, NC & $76.57^{\mathrm{ab}}$ & 1.98 & 1.42 & 0.46 & 3.86 & 0.09 & 0.29 \\
\hline $\mathrm{NC}+0.5 \mathrm{~g}$ lecithin & $75.15^{\mathrm{bc}}$ & 2.21 & 1.45 & 0.49 & 4.15 & 0.06 & 0.22 \\
\hline $\mathrm{NC}+0.2 \mathrm{~g}$ xylanase & $78.13^{\mathrm{a}}$ & 2.09 & 1.45 & 0.48 & 4.02 & 0.07 & 0.28 \\
\hline $\begin{array}{l}\mathrm{NC}+0.5 \mathrm{~g} \text { lecithin }+0.2 \mathrm{~g} \\
\text { xylanase }\end{array}$ & $74.71^{\mathrm{c}}$ & 2.02 & 1.43 & 0.55 & 4.00 & 0.08 & 0.28 \\
\hline \pm S.E & \pm 0.52 & \pm 0.12 & \pm 0.09 & \pm 0.05 & \pm 0.20 & \pm 0.02 & \pm 0.08 \\
\hline Sig. & $* * *$ & NS & NS & NS & NS & NS & NS \\
\hline
\end{tabular}

$\mathrm{a}, \mathrm{b}$...c means having different letters at the same column are significantly $(\mathrm{P}<0.05)$ different.

$\mathrm{NS}=$ not significant $\quad * * *=(\mathrm{P}<0.001)$ 
The improvement carcass percent in $\mathrm{NC}+0.2 \mathrm{~g}$ xylanase group may be due to that xylanase could release more energy, hence increase carcass\% (Selim et al., 2018). Whereas, other studies show that enzyme supplementation may improve the growth rate of broilers (Khan et al., 2006) by enhancing the absorption of starch, amino acids (Ziggers, 2006 and Serena et al., 2009).

\section{Physical meat quality}

Table 3 represents the effect of lecithin, xylanase enzyme supplementation and their interaction on Drip loss and $\mathrm{pHu}$ (physical meat quality measurements). The determined drip loss $\%$ of different broiler cuts showed significant reduction values in group of $\mathrm{NC}+0.5 \mathrm{~g}$ lecithin for both thigh and breast meat with a reduction percentage for thigh by $26.1 \%$ and $48 \%$ compared to control and $\mathrm{NC}$, respectively. Moreover, a decrease $\%$ for breast was
$30.1 \%$ and $71 \%$ compared to control and $\mathrm{NC}$, respectively. Regarding to $\mathrm{pHu}$ values, it is worthy to note that none of the treatments show any significant varation between them. These results agree with Zakaria et al. (2010) who recorded that the addition of mixture enzymes did not significantly impact $\mathrm{pH}$ meat quality traits of broiler. Also, Selim et al.(2016) found that broilers fed diets less 100 or $150 \mathrm{Kcal} / \mathrm{kg}$ diet than standard diet had significant increase in drip loss by 36 and $46.4 \%$, respectively. In the present study, the reduction in drip loss \% as a result of soylecithin may be due to that it contains phospholipids which increases the radical-scaving activity of vitamin $\mathrm{E}$, then protecting the cell from oxidation (Koya and Terao, 1995). Then increase the ability of breast and thigh meat for processing, moreover, improve water holding capacity (Barbut, 1993 and Zhang and Savage, 2010).

Table 3. Effect of different treatments on physical meat quality.

\begin{tabular}{lcccc}
\hline \multicolumn{1}{c}{ Treatments } & \multicolumn{2}{c}{ Drip loss\% } & \multicolumn{2}{c}{$\mathrm{pHu}$} \\
\cline { 2 - 5 } & Thigh & Breast & Thigh & Breast \\
\hline Control & $0.88^{\mathrm{ab}}$ & $1.03^{\mathrm{b}}$ & 6.39 & 6.14 \\
Negative control, NC & $1.25^{\mathrm{a}}$ & $2.48^{\mathrm{a}}$ & 6.29 & 6.13 \\
$\mathrm{NC}+0.5$ g lecithin & $0.65^{\mathrm{b}}$ & $0.72^{\mathrm{b}}$ & 6.49 & 6.15 \\
$\mathrm{NC}+0.2$ g xylanase & $1.04^{\mathrm{ab}}$ & $2.36^{\mathrm{a}}$ & 6.45 & 6.13 \\
NC +0.5 g lecithin + 0.2 g xylanase & $1.12^{\mathrm{a}}$ & $1.01^{\mathrm{b}}$ & 6.36 & 6.46 \\
\pm S.E & \pm 0.12 & \pm 0.41 & \pm 0.24 & \pm 0.16 \\
Sig. & $*$ & $* *$ & $\mathrm{NS}$ & $\mathrm{NS}$ \\
\hline
\end{tabular}

$\mathrm{a}, \mathrm{b} \ldots . \mathrm{d}$ means having different letters at the same column are significantly $(\mathrm{P}<0.05)$ different.

$\mathrm{NS}=$ not significant $\quad *=(\mathrm{P}<0.05) \quad * *=(\mathrm{P}<0.01)$

\section{Chemical meat quality}

Results of chemical meat quality parameters of broiler chicks fed diet supplemented with lecithin, xylanase or lecithin + xylanase are shown in Table (4). All tested groups decreased meat total saturated fatty acids compared to control and NC. On the other side, total poly-unsaturated fatty acids were significantly increased in these treated groups than others fed either control or NC diets. In respect of chemical meat quality, triglycerides, total cholesterol and LDL levels were significantly reduced in groups fed NC diet and supplemented with either $0.5 \mathrm{~g} / \mathrm{kg}$ lecithin, $0.2 \mathrm{~g} / \mathrm{kg}$ xylanase or the combination between them compared with control and NC. While, HDL values were significantly increased. These obtained results are in partial agreement with, Mu and Kitts (2018) who studied the effect of replacing $2.5 \%$ tallow with graded levels of soy-lecithin $(0$, $25 \%, 50 \%$ and $100 \%$ ) on broilers meat composition of fatty acids and, found that chicks fed diets contained 50 and $100 \%$ soy lecithin achieved significantly $(\mathrm{P}<0.05)$ higher polyunsaturated fatty acids (PUFAs) in breast and leg muscles, respectively compared to broiler fed 0 and $25 \%$ soy lecithin. Moreover, the same authors found no effect in saturated fatty acids with feeding lecithin in both breast and leg meat. Also, Dubey (2009) reported that broilers fed diet contained 2, 2.5 and $3 \%$ crude soy lecithin (CSL) reduce total cholesterol in breast and thigh compared to control, $1 \%$ and $1.5 \%$ CSL. While, the chemical quality measurements of broiler meat including LDL and HDL did not changed by supplementing low-energy diet $(-100$ and $-150 \mathrm{Kcal} /$ $\mathrm{kg}$ diet) with a single dose of xylanase Selim $\boldsymbol{e t}$ al. (2015) or pectinase (Selim et al., 2016).

In current study, lecithin acts as an emulsifier which could distribute oil droplets evently in the emulsion and enhance the absorption and digestion of lipids so decrease lipid in meat (Rovers, 2014). Moreover, regarding to lecithin antioxidant properties, it makes synergistic action with $\alpha$-tocopherol to stabilize PUFAs against lipid oxidation (Koga and Terao, 1995). 
Table 4. Effect of different treatments on chemical meat quality.

\begin{tabular}{|c|c|c|c|c|c|c|c|}
\hline \multirow[b]{2}{*}{ Treatments } & \multicolumn{7}{|c|}{ Chemical meat quality } \\
\hline & $\begin{array}{c}\text { TSFA } \\
\text { (mg/100g } \\
\text { fat) }\end{array}$ & $\begin{array}{c}\text { TMUSFA } \\
\text { (mg/100g } \\
\text { fat) }\end{array}$ & $\begin{array}{c}\text { TPUSFA } \\
(\mathrm{mg} / 100 \mathrm{~g} \\
\text { fat })\end{array}$ & $\begin{array}{c}\text { Triglycerides } \\
(\mathrm{mg} / \mathrm{dl})\end{array}$ & $\begin{array}{c}\text { Cholesterol } \\
(\mathrm{mg} / \mathrm{dl})\end{array}$ & $\begin{array}{c}\text { HDL } \\
(\mathrm{mg} / \mathrm{dl})\end{array}$ & $\begin{array}{c}\text { LDL } \\
(\mathrm{mg} / \mathrm{dl})\end{array}$ \\
\hline Control & $2089.67^{\mathrm{a}}$ & 1792.67 & $890.33^{\mathrm{d}}$ & $61.13^{\mathrm{a}}$ & $143.23^{\mathrm{a}}$ & $87.36^{\mathrm{ab}}$ & $39.20^{\mathrm{a}}$ \\
\hline $\begin{array}{l}\text { Negative } \\
\text { control, } \\
\text { NC }\end{array}$ & $1997.67^{b}$ & 1842.00 & $931.33^{c}$ & $60.50^{\mathrm{a}}$ & $139.83^{\mathrm{b}}$ & $86.27^{b}$ & $37.57^{\mathrm{b}}$ \\
\hline $\begin{array}{l}\mathrm{NC}+0.5 \\
\mathrm{~g} \text { lecithin }\end{array}$ & $1511.00^{\mathrm{e}}$ & 2049.00 & $1138.00^{\mathrm{a}}$ & $51.57^{\mathrm{c}}$ & $128.43^{\mathrm{d}}$ & $91.25^{\mathrm{a}}$ & $34.33^{\mathrm{c}}$ \\
\hline $\begin{array}{l}\mathrm{NC}+0.2 \\
\mathrm{~g} \\
\text { xylanase }\end{array}$ & $1592.00^{\mathrm{d}}$ & 1995.00 & $1127.00^{\mathrm{a}}$ & $55.90^{\mathrm{b}}$ & $137.80^{\mathrm{b}}$ & $86.62^{\mathrm{b}}$ & $35.37^{\mathrm{c}}$ \\
\hline $\begin{array}{l}\mathrm{NC}+0.5 \\
\mathrm{~g} \text { lecithin } \\
+0.2 \mathrm{~g} \\
\text { xylanase }\end{array}$ & $1814.00^{c}$ & 1608.00 & $995.00^{\mathrm{b}}$ & $52.33^{\mathrm{c}}$ & $132.67^{\mathrm{c}}$ & $90.68^{a}$ & $35.23^{\mathrm{c}}$ \\
\hline $\begin{array}{l} \pm \text { S.E } \\
\text { Sig. }\end{array}$ & $\begin{array}{c} \pm 7.54 \\
* * *\end{array}$ & $\begin{array}{c} \pm 132.10 \\
\text { NS }\end{array}$ & $\begin{array}{c} \pm 5.58 \\
* * *\end{array}$ & $\begin{array}{c} \pm 0.82 \\
* * *\end{array}$ & $\begin{array}{c} \pm 1.08 \\
* * *\end{array}$ & $\begin{array}{c} \pm 1.20 \\
*\end{array}$ & $\begin{array}{c} \pm 0.40 \\
* * *\end{array}$ \\
\hline
\end{tabular}

TSFA=total saturated fatty acids, TMUSFA $=$ total mono-unsaturated fatty acids, TPUSFA $=$ total poly-unsaturated fatty acids $\mathrm{a}, \mathrm{b} \ldots . . \mathrm{e}$ means having different letters at the same column are significantly $(\mathrm{P}<0.05)$ different.

$\mathrm{NS}=$ not significant $\quad *=(\mathrm{P}<0.05) \quad * * *=(\mathrm{P}<0.001)$

\section{Blood constituents}

Results in Table 5, show no significant effect on plasma AST and ALT values. These results are in harmony with Saleh $\boldsymbol{e t}$ al. (2019) who found that liver function indicators (AST, ALT) were not significantly affected by adding xylanase to broilers fed low-energy diet and illustrated that xylanase might be safe in poultry rations without negative effects on vital organ functions (liver). Also, Rahnama et al. (2019) with supplementation lecithin in broilers diet. Regarding to plasma lipid profile, all groups of NC and others fed NC added with different feed additives recorded significantly lower total cholesterol, triglycerides and LDL than the control. While the opposite situation was recorded for HDL, which all tested groups recorded higher HDL values than control.

These obtained results agree with recent research of, Liu et al. (2020) who found that adding $61.80 \%$ and $97.16 \%$ de-oiled lecithin to broilers diets resulted in significant increase in serum HDL and decrease serum LDL compared to control. They related this improvement to the better emulsification of supplementation of lecithin, so it can effectively and fully use of fat. Also, blood serum HDL/C and LDL/C contents support the lipid metabolism.

Table 5. .Effect of different treatments on plasma blood parameters.

\begin{tabular}{|c|c|c|c|c|c|c|}
\hline \multirow[b]{2}{*}{ Treatments } & \multicolumn{2}{|c|}{ Liver enzymes } & \multicolumn{4}{|c|}{ Lipid profile } \\
\hline & $\begin{array}{c}\text { AST } \\
\mathbf{u} / \mathbf{l}\end{array}$ & $\begin{array}{c}\text { ALT } \\
\mathbf{u} / \mathbf{l}\end{array}$ & $\begin{array}{c}\text { Total } \\
\text { cholesterol } \\
(\mathrm{mg} / \mathrm{dl})\end{array}$ & $\begin{array}{c}\text { Triglycerides } \\
\text { (mg/dl) }\end{array}$ & $\begin{array}{c}\text { HDL } \\
(\mathrm{mg} / \mathrm{dl})\end{array}$ & $\begin{array}{c}\text { LDL } \\
(\mathrm{mg} / \mathrm{dl})\end{array}$ \\
\hline Control & 16.67 & 27.00 & $219.00^{\mathrm{a}}$ & $44.33^{\mathrm{a}}$ & $135.33^{\mathrm{c}}$ & $53.67^{\mathrm{a}}$ \\
\hline Negative control, NC & 18.33 & 26.67 & $197.33^{\mathrm{ab}}$ & $29.67^{\mathrm{bc}}$ & $145.00^{\mathrm{b}}$ & $37.33^{\mathrm{b}}$ \\
\hline $\mathrm{NC}+0.5 \mathrm{~g}$ lecithin & 17.33 & 27.33 & $179.33^{\mathrm{b}}$ & $29.33^{\mathrm{bc}}$ & $146.87^{\mathrm{b}}$ & $24.67^{\mathrm{c}}$ \\
\hline $\mathrm{NC}+0.2 \mathrm{~g}$ xylanase & 16.67 & 25.67 & $190.67^{b}$ & $34.67^{\mathrm{b}}$ & $146.67^{\mathrm{b}}$ & $39.00^{\mathrm{b}}$ \\
\hline $\begin{array}{l}\mathrm{NC}+0.5 \mathrm{~g} \text { lecithin }+0.2 \mathrm{~g} \\
\text { xylanase }\end{array}$ & 19.00 & 27.33 & $189.00^{\mathrm{b}}$ & $27.00^{\mathrm{c}}$ & $157.80^{\mathrm{a}}$ & $23.33^{c}$ \\
\hline \pm S.E & \pm 1.19 & \pm 1.62 & \pm 7.27 & \pm 1.72 & \pm 2.60 & \pm 4.00 \\
\hline Sig. & NS & NS & $*$ & $* * *$ & $* * *$ & $* * *$ \\
\hline
\end{tabular}

a, b...c means having different letters at the same column are significantly $(\mathrm{P}<0.05)$ different.

$\mathrm{NS}=$ not significant $\quad *=(\mathrm{P}<0.05) \quad * * *=(\mathrm{P}<0.001)$

On contrary, Dubey (2009) found that chicks fed diet containing different levels of crude soy lecithin $(0,1$, $1.5,2,2.5$ and $3 \%$ ) had no significant effect on serum cholesterol, HDL and ALT. Also, these results are coincident with the findings of Saleh $\boldsymbol{e t}$ al. (2019) who reported that plasma HDL was significantly increased and total cholesterol decreased in broilers fed low-energy diet supplied with xylanase compared to control, such this improvement might be due to enhance the fat digestibility hence improve its absorbtion. 


\section{Conclusion}

In conclusion, broiler chicks fed low energy diet ($150 \mathrm{Kcal} / \mathrm{kg}$ diet) supplemented with single dose of $0.5 \mathrm{~g}$ lecithin, $0.2 \mathrm{~g}$ xylanase or combination between them enhanced carcass relative weight, increased blood plasma HDL concentration, decreased plasma LDL, total cholesterol and triglycerides and improved meat quality.

\section{Reference}

Aura, A.; Forssell, P.; Mustranta, A. and Poutanen, K. (1995): Transesterification of soy lecithin by lipase and phospolipase. J. Amer. Oil Chem. Soc., 72: 1375 - 1379.

Barbut, S. (1993). Colour measurements for evaluating the pale soft exudative (PSE) occurrence in turkey meat. Food Res. Int., 26: 39 $-43$.

Borsatti, L.; Vieira, S. L.; Stefanello, C.; Kindlein, L.; Oviedo-Rondón, E. O. and Angel, C. R. (2018). Apparent metabolizable energy of byproducts from the soybean oil industry for broilers: acidulated soapstock, glycerin, lecithin, and their mixture. Poult Sci., 97:124 - 130.

Bueschelberger, H. G.; Tirok, S.; Stoffels, I. and Schoeppe. A. (2015). Lecithins in Emulsifiers in Food Technology, 2nd Edition. V. Norn, ed. John Wiley \& Sons, Hoboken, NJ Pages 21-60

Cowieson, A. J.; Bedford, M. R. and Ravinran, V. (2010). Interactions between xylanase and glucanase in maize-soy-based diets for broilers. Br. Poult. Sci., 51: 246 - 257.

Dubey, M. (2009). Effect of dietary soy acid oil and crude soy lecithin on growth performance, nutrient utilization and biochemical profile in VEN-COBB on broiler chicken. Ph.D. Thesis, College of Veterinary Science and Animal Husbandry, Anjora, Durg. India.

Duncan, D. B. (1955): Multiple range and multiple F tests. Biometrics., 11: 1 - 42.

Hajati, H. (2010). Effects of enzyme supplementation on performance, carcass characteristics, carcass composition and some blood parameters of broiler chicken. Amer. J. Anim. Vet. Sci., 5: 221 - 227.

Hussein, E. O. S.; Suliman, G. M.; Abudabos, A. M.; Alowaimer, A. N.; Ahmed, S. H.; Abd ElHack, M. E.; Alagawany, M.; Swelum, A. A.; Tinelli, A.; Tufarelli, V. and Laudadio, V. (2019). Effect of a low-energy and enzymesupplemented diet on broiler chicken growth, carcass traits and meat quality. Arch. Anim. Breed., 62: 297 - 304.

Khan, S. H.; Sardar, R. and Siddique, B. (2006). Influence of enzymes on performance of broilers fed sunflower corn based diets. Pak. Ver. J., 26: $109-114$.

Kocher, A.; Choct, M.; Ross, G.; Broz, J. and Chung, T. K. (2003). Effects of enzyme combinations on apparent metabolizable energy of corn-soybean meal based diets in broilers. J. Appl. Poult. Res., 12: 275 - 283.

Koga, T. and Terao, J. (1995). Phospholipids increase radical-scavenging activity of vitamin $\mathrm{E}$ in a bulk oil model system. J Agric Food Chem., 43: 1450 - 1454.

Liu, X.; Yoon, S. B. and Kim, I. H. (2020). Growth performance, nutrient digestibility, blood profiles, excreta microbial counts, meat quality and organ weight on broilers fed with de-oiled lecithin emulsifier. Animals., 10: 478 - 489.

Mateos, G. G.; Serrano, M. P.; Berrocoso, J.; Pérez-Bonilla, A. and Lázaro. R. (2012). Improving the utilization of raw materials in poultry feeding: new technologies and inclusion levels. Proceedings of 24th World's Poultry Congress, Bahia-Salvador, Brazil, 5-9 August 2012, pp. 1-13.

Meng, X.; Slominski, B. A.; Nyachoti, C. M.; Campbell, L. D. and Guenter, W. (2005). Degradation of cell wall polysaccharides by combinations of carbohydrase enzymes and their effect on nutrient utilization and broiler chicken performance. Poult. Sci., 84: 37 - 47.

Mu, K. and Kitts, D. D. (2018). Use of soy lecithin to improve nutritional quality of poultry meats and its effect on stability and sensory attributes. J. Nutr. Food Sci., 8: 714 - 722.

Nasoetion, M.; Atmomarsono, U.; Sunarti, D. and Suthama, N. (2019): Growth performance and lipid profile of broilers fed different levels of purple sweet potato extract and raised under different stocking densities. Livestock Research for Rural Development., 31: 135 - 141.

NRC. (1994): National Research Council, Nutrient requirement of poultry. $9^{\text {th }} \mathrm{Ed}$, National Academy of Science. Washington, D. C., USD.

Olukosi, O. A. and Adeola, O. (2008). Whole body nutrient accretion, growth performance and total tract nutrient retention responses of broilers to supplementation of xylanase and phytase individually or in combination in wheat-soybean meal based diets. J. Poult. Sci., 45: $192-198$.

Omar, A.W.; Khataibeh, M. H. and Abu-Alruz, K. (2008). The use of xylanases from different microbial origin in bread making and their effects on bread quality. J. Appl. Sci., 8: 672 - 676.

Patterson, E.; Wall, R.; Fitzgerald, G.F.; Ross, R.P. and Stanton, C. (2012) Health implications of high dietary Omega-6 polyunsaturated fatty acids. J. Nutr. Metab., 2012: 1 - 16.

Rahnama, M., Bouyeh, M.; Kadim, I.; Seidavi, A.; Elghandour, M. M. Mona.; Reddy, P. R. K.; Monroy, J. C. and Salem, A. Z. M. (2009). Effect of dietary inclusion of lecithin with choline on physiological stress of serum cholesterol fraction and enzymes, abdominal fat, growth performance, and mortality parameters of broiler 
chickens. Animal Biotechnology. 31(6): $483-$ 490.

Ravindran, V.; Tancharoenrat, P.; Zaefarian, F. and Ravindran. G. (2016). Fats in poultry nutrition: Digestive physiology and factors influencing their utilisation. Anim. Feed Sci. Technol. 213: $1-21$.

Reitman, S. and Frankel, S. (1957). Am. J. Clin. Path., 28: 56 - 63.

Richmond, W. (1973). Clin. Chem., 19: 1350.

Rovers, M. (2014). Saving energy and feed cost with nutritional emulsifier. Intl. Poult. Prod., 22: $7-8$.

Saenmahayak, B.; Singh, M.; Bilgili, S. F. and Hess, J. B. (2012). Influence of dietary supplementation with complexed zinc on meat quality and shelf life of broiler. Int. J. Poult. Sci., 11: 28 - 32 .

Saleh, A. A.; Kirrella, A. A.; Abdo, E. S.; Mousa, M. M.; Badwi, A. N.; Ebeid, A. T.; Nada, L. A. and Mohamed, A. M. (2019). Effects of dietary xylanase and arabinofuranosidase Combination on the growth performance, lipid peroxidation, blood constituents, and immune response of broilers fed low-energy diets. J. Anim., 9: 467 478.

Sarica, S.; Ciftci, A.; Demir, E.; Kilinc, K. and Yildirim, Y. (2005). Use of an antibiotic growth promoter and two herbal natural feed additives with and without exogenous enzymes in wheat based broiler diets. S. Afr. J. Anim. Sci., 35: 61 72.

SAS Institute (2004). SAS User's Guide. Release 8.2. Ed. SAS Institute Inc. Cary. NC.

Selim N. A.; Waly H. Amany; Abdel Magied A. Hemat; Habib, H. Heba; A.A. Fadl and S.M. Shalash (2015). Further benefits of xylanase enzyme supplementation to low energy cornsoybean meal broiler diets. Egyptian J. Nutrition and Feeds., 18: 443 - 456

Selim, N. A.; Abdel Magied, A. H.; Habib, H. H.; Waly, H. A.; Fadl, A.A. and Shalash, S.M. (2016). Effect of pectinase enzyme supplementation and low energy corn-soybean meal diets on broiler performance and quality of carcass and meat. Egypt. Poult. Sci., 36 : $319-$ 335.

Selim, N. A.; Abdel Magied, H. A.; Habib, H. H.; Waly, A. H.; Fadl, A. A. and Shalash, S. M. (2019). Using protease and xylanase enzymes as single or combined supplementation to cornSoybean meal broiler diets. EC. Vet. Sci., 4: 637 652.

Selim, N. A.; Nada, Sh. A.; Abdel-Salam, A. F. and Youssef, S. F. (2013). Evaluation of some natural antioxidant sources in broiler diets: 2Effect on chemical and microbiological quality of chilled and frozen broiler meat. Int. J. Poult. Sci., 12: 572 - 581.

Selim, N.A.; Waly, A. H.; Abdel Magied, H. A.; Habib, H. H.; Fadl, A.A. and Shalash, S.M. (2018). A study on synergism between two different supplemental carbohydrases enzymes to standard or low energy broiler. Egypt. Poult. Sci., 38: $1207-1228$.

Serena, A.; Jorgensen, H. and Bach, K. (2009). Absorption of carbohydrate-derived nutrients in sows as influenced by types and contents of dietary fiber. J. Anim. Sci., 87: 136 - 147.

Siyal, F. A.; El-Hack, M. E. A.; Alagawany, M.; Wang, C.; Wan, X. L.; He, J. T.; Wang, M. F.; Zhang, L. L.; Zhong, X.; Wang, T. and Dhama, K. D. (2017). Effect of soy lecithin on growth performance, nutrient digestibility and hepatic antioxidant parameters of broiler chickens. Int. J. Pharmacol., 13: 396 - 402.

Soloni, F. G. (1971). Simplified manual micro method for determination of serum triglyceride. Clinical Chemistry, 17: 529 - 534.

van Nieuwenhuyzen, W. and Tomás, M. C. (2008). Update on vegetable lecithin and phospholipid technologies. Eur. J. Lipid Sci. Technol. 110: 472 -486 .

Williams, M. P.; Klein, J. T.; Wyatt, C. L.; York, T. W. and Lee, J. T. (2014). Evaluation of xylanase in low-energy broiler diets. J. Appl. Poult. Res. $23: 1-8$.

Zakaria, H. A. H.; Jalal, M. A. R. and Ishmais, M. A. A. (2010). The influence of supplemental multi-enzyme feed additive on the performance, carcass characteristics and meat quality traits of broiler chickens. Int. J. Poult. Sci., 9:126 - 133.

Zhang, H. and E. M. Savage (2010). Comparisons of sensory descriptive flavor and texture profiles of cooked broiler breast fillets categorized by raw meat color lightness values. Poult. Sci. 89:10491055 .

Ziggers, D. (2006). NSP-enzyme in corn-soybean rations. Fed. Tech., 10: $30-31$. 


\section{تأثير اضافة ليسيثين الصويا والزيلانيز والتذاخل بينهم للعلائق المنخفضة فى الطاقة على صفات الذبيحة وجودة الأبيحة وجودة اللحم ويعض مقاييس الام لاجاج التسمين \\ زنجبيل سعد محمد السيد1, أميرة محمود رفاعى2 , جمال على الاين الصياد1 , محمد محمد عبداللاه1

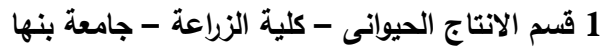 \\ 2 معهر بحوث الانتاج الحيوانى - مركز البحوث النزاعية - الدقى - الجيزة - مصر النئ}

تهدف هذه الدراسة الى التحقق من علاقة التآزر بين اللبسيثين وإنزيم الزيلانيز عند اضافتهم لعلائق منخفضة الطاقة على خواص

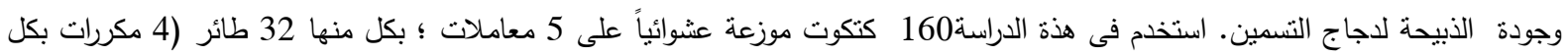

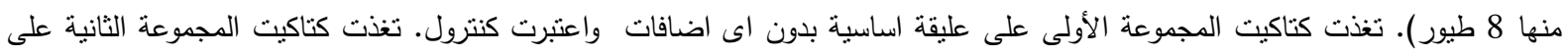
عليقة منخفضة الطاقة (-150 كيلوكالوري / كجم أقل من الموصى به) واعنبرت كنترول سالب. تغذت كتاكيت المجموعات الثالثة والرابعة الثات والخامسة على عليقة الكنترول السالب مضاف إليها 0,5 جم ليسيثين/كجم و 0,2 جم زيلانيز /كجم و 0,5 جم ليسيثين + 0,2 جم زيلانيز / /

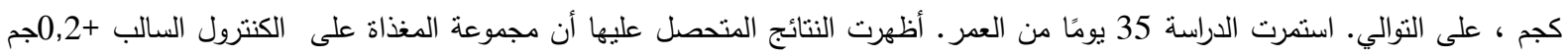
زيلانيز / كجم سجلت زيادة معنوية في الاوزان النسبية للذبيحة. حققت المجموعة المغذاة على الكنترول السالب +0,5 جم ليسيثين /كجم أقل

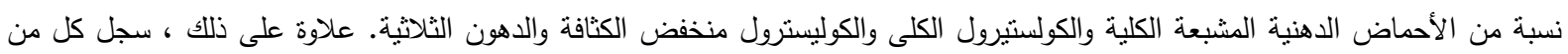

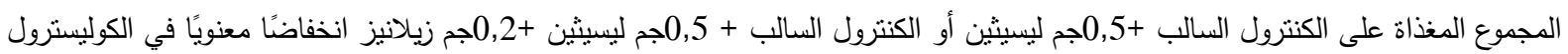
الكلي ، والدهون الثلاثية والكولستيرول منخفض الكثافة في بلازما الدم ، وزيادة في كولستيرول عالى الكثافة في بلازما الدم مقارنة بالكنترول. الخلاصة:- إضافة 0,5 جم من الليسيثين بمفرده أو مع 0,2 جم زيلانيز إلى علائق دجاج التسمين منخفضة الطاقة يكون أكثر فاعلية على الذبيحة وجودة اللحوم ودهون بلازما الدم. 